\title{
The Characteristic of Porang Flour (Amorphophallus muelleri Blume) Purification Use Ethanol and The Application as Subtitution Agent on Chicken Sausage
}

\author{
Yovy Ermawati1), Noor Harini2), and Sri Winarsih2)* \\ 1) Student of food science and technology department, Agriculture and Animal Science Faculty, \\ Muhammadiyah University of Malang, Indonesia \\ 2) Food Science and Technology Department, Agriculture and Animal Science Faculty, University of \\ Muhammadiyah Malang, Indonesia \\ * Corresponding author: sriwinarsih26@gmail.com
}

\begin{abstract}
Porang flour contains high glucomanan which can reach $65 \%$. This research purposed to analyze the physical and chemical of porang flour prurification use ethanol, and to describe the effect of proportion of tapioca and porang flour addition to the physical, chemical, and organoleptic of chichken sausage. Randomized Complete Block Design was applied with two phase. The first stage was purification process used ethanol with diffence concentration $(60 \%, 75 \%$, and $90 \%)$. The second phase was the addition of porang and tapioca flour (gram) (0:20, $1: 19,2: 18,3: 17,4: 16,5: 15,6: 14$ ), all treatment was replicated 3 times. The results of first process showed that, there was very significance difference effect to the glucomanan, rendemen, viscosity, and colour (lightness and yellowish) of porang flour. The best treatment was the purification by ethanol $90 \%$ with $11,2 \%$ water content, $0,78 \%$ ash content, 58,20\% glucomanan, 78, 11\% rendemen, and 3,33 dPas viscosity. The second treatment results described that, there was very significance effect of tapioca and porang flour addition to the water content, ash content, fat, protein, carbohydrate, colour intensity $\left(\mathrm{L}, \mathrm{a}^{+}\right.$, and $\left.\mathrm{b}^{+}\right)$, and organoleptic (taste, aroma, appearance, and favorite product) of chicken sausage.
\end{abstract}

Key Words: porang flour, ethanol, chicken sausage

\section{Introduction}

Sausage is an innovation food product obtained to fine meat (not less than $75 \%$ ) mixing by starch which able to add with or without spices, and other food additives that are allowed and incorporated into a sausage shell (SNI, 1995). The main problems that often arise in the manufacture of sausages is a weak texture (not compact), too hard or too soft, and low water holding capacity. Therefore, to get a chicken sausage with a good texture, it is necessary add of filler and binder. The commonly used filler is tapioca flour. The excessive tapioca flour usage can make the sausage texture become so hard. In that order, the innovative ingredients are needed to be substituted with tapioca flour as a filler in making chicken sausage. Porang flour contains high glucomannan that can reach $65 \%$, which able to improve the quality of chicken sausage. Glucomannan is a water-soluble polysaccharide having hydrocolloid properties with Water Holding Capacity (WHC) value up to 1900\% which able to improve temperature stability, as thickener, and wax (Herlina, 2012). The process of chicken sausage making with porang flour is started by producing gel porang. Creating chicken sausage using porang flour directly as a filler can produce lower physical quality than ideal standard. 
The porang glucomanan purification researchs has been widely practiced in Indonesia. However, the problem which always appear is the low brightness and glucomannan level. This is suspected because, the purity process or proportion of porang addition haven't definetly standard. Therefore, preliminary research before applicate the porang flour as filler in chicken sausages is needed. The purification of porang flour commonly uses ethanol. According to Eka (2014), purification porang flour using ethanol can dissolve the impurities, while glucomannan does not dissolve in ethanol. Hence, it is necessary to analyze the effect of different ethanol concentration to the porang flour purification process. The aimed of this research was to analyze the effect of different ethanol concentration to the physical and chemical properties of porang flour, and to investigate the physical, chemical and organoleptic characteristics of chicken sausage due to proportion porang and tapioca flour.

\section{Material and Method}

This research was conducted in Food Science and Technology Laboratory University of Muhammadiyah Malang. The raw materials were chicken breast, porang flour, sea grass (Euchema cottonii), KOH, aquades, ethanol (60\%; $75 \%$ and $90 \%$ ), and tapioca starch. While solvent which apllied on analysis are aluminum sulfate salt, water, isopropyl alcohol, $\mathrm{H} 2 \mathrm{SO} 4(93-98 \%$ free $\mathrm{N}), \mathrm{NaOH} 50 \%, \mathrm{HCl} 0.02 \mathrm{~N}$, zinc granules, boric acid and petroleum ether. This research consisted of 2 stages, the first phase was porang flour production and the second one was porang and tapioca flour application for chicken sausage production. The first process parameters were glucomannan, rendemen, viscosity and color of porang flour. While the parameters of second phase were physical, chemical and also organoleptic characteristics of chicken sausage.

Statistical analysis: This research applied the Randomized Complete Block Design (RCBD). All treatment in both of stages were replicated 3 times. The results were analyzed used ANOVA (Analyzed of Variance). The first stage treatment consisted of $60 \%, 75 \%$ and $90 \%$, ethanol addition. While the second stage consisted of 7 level treatment (porang and tapioca flour). The proportion was shown the Table 1.

Table 1.The proportion of porang flour and tapioca flour

\begin{tabular}{llllllll}
\hline Treatment & S1 & S2 & S3 & S4 & S5 & S6 & S7 \\
\hline Porang (g) & 0 & 1 & 2 & 3 & 4 & 5 & 6 \\
Tapioca (g) & 20 & 19 & 18 & 17 & 16 & 15 & 14 \\
\hline
\end{tabular}

\section{Results and Discussion}

First Stage. The parameters of first stage consisted of:

\section{Glucomanan}

The treatment of porang flour purification used ethanol gave significant effect to the glucomannan (Tabel 2). The results showed that glucomannan content ranges from $48.07 \%$ to $58.20 \%$. The trend was directly propotional, it means that increasing 
ethanol concentration was followed by enhanching glucomannan content. This is caused by the difference concentration will affects to the ethanol purity which automaticly will affect to the glucomannan production. Shiroh (2000) stated that the extraction process which followed by impurities separation from glucomannan gave better product. Glucomannan produced by addition of ethanol then dried and mashed obtain to glucomannan flour.

Table 2.Glucomanan content of porang flour based on purification process use ethanol

\begin{tabular}{cll}
\hline Ethanol Concentration (\%) & Glucomanan (\%) & \\
\hline 60 & 48,07 & $\mathrm{~A}$ \\
75 & 51,95 & $\mathrm{~B}$ \\
90 & 58,20 & $\mathrm{C}$ \\
\hline
\end{tabular}

\section{Rendemen}

The purification treatment using ethanol with different concentrations was significantly affect to the porang flour rendement (Table 3). The results indicated that the average yield ranged from $77.34-78.11 \%$. The results showed inversly proportional, the enhanching ethanol concentration used followed by decreasing the rendemen. According to Tadahiko (2003), ethanol and water in the glucomannan purification process serve to rinse and precipitate glucomannan, thus it able to increase glucomannan levels up to $90 \%$ or more.

Table 3. The effect of on purification process use ethanol to the rendemen

\begin{tabular}{ccc}
\hline Ethanol Concentration (\%) & Rendemen (\%) & \\
\hline 60 & 78,11 & $\mathrm{~b}$ \\
75 & 77,96 & $\mathrm{~b}$ \\
90 & 77,34 & $\mathrm{a}$ \\
\hline
\end{tabular}

\section{Viscosity}

The purification treatment using ethanol was affect to the viscosity of porang flour (Table 4). The results showed that average viscosity of porang flour ranges from 2.27 - $3.33 \mathrm{dPas}$. The increasing concentration of ethanol followed by increasing glucomannan content and it will affect to the enhanching viscosity of porang flour. Glucomannan was found able to increase the viscosity because of it dissolved into water. In addition, the viscosity is related to the water absorption properties, where per $1 \mathrm{~g}$ of glucomannan will absorb water by $100 \mathrm{~g}$ of water. According to (Yusuf, 2011), glucomannan levels play an important role in increasing the viscosity of porang flour because glucomannan is thick.

Table 4. Viscosity of Porang Flour based on on purification process use ethanol

\begin{tabular}{cll}
\hline Ethanol Concentration (\%) & Viscosity (dPas) & \\
\hline 60 & 2,27 & $\mathrm{a}$ \\
75 & 2,67 & $\mathrm{a}$ \\
90 & 3,33 & $\mathrm{~b}$ \\
\hline
\end{tabular}




\section{Colour Intensity}

The purification treatment using ethanol with different concentrations affected significantly to the brightness scale (L) and yellowish $\left(b^{+}\right)$(Table 5) but it was unsignificant to the reddish $\left(\mathrm{a}^{+}\right)$(Figure 1). The result showed that color intensity on lightness ranged from 51.93 - 54.57. The increasing concentration of ethanol increased the porang flour brightness. This was due to ethanol effectivly to eliminate the dye in the porang flour. While the yellowish scale $\left(\mathrm{b}^{+}\right)$ranged from 5.4 to 7.77 and it was directly proportionally. This is because of purification process use ethanol will dissolve impurities which cause flour colour become dark brown, as the results the porang flour color becomes more yellow, such as porang tuber. The ethanol concentration for purification process was not significantly to the reddish colour and the scale ranged from 13.97 - 17.27.

Table 5. Viscosity of Porang Flour based on on purification process use ethanol

\begin{tabular}{cll}
\hline Ethanol Concentration (\%) & Lightness (L) & Yellowish $\left(\mathbf{b}^{+}\right)$ \\
\hline 60 & $51,93 \mathrm{a}$ & 5,40 \\
75 & $53,17 \mathrm{~b}$ & 6,77 \\
90 & $54,57 \mathrm{c}$ & 7,77 \\
\hline
\end{tabular}

\section{Second Stage}

De Garmo test was used for identified the best treatment. The second stage used the raw material porang flour which washed by $90 \%$ ethanol concentration. The water content of chicken sausage ranged from $70.06-74.37 \%$ (Table 6). The increasing porang flour enhanced the water content of the chicken sausage. This due to porang flour contains glucomannan, which is capable of binding water. In addition, based on the analysis, the water content of porang flour reached $11.76 \%$. According to Eka (2014), glucomanan is a water soluble polysaccharide having hydrocolloid properties with Water Holding Capacity (WHC) value up to $1900 \%$.

The carbohydrate content of chicken sausages ranged from 5.8 to $11.26 \%$ (Table 6). The enhancment of porang flour decreased carbohydrate level in the chicken sausage. The biggest component of tapioca is starch. Starch is the second largest carbohydrate reserve after cellulose on plant tissue. Starch contains two major component tissues of amylose and amylopectin. According to Agustina (2011), carbohydrate content of tapioca starch is $88,2 \%$.

The chicken sausage texture ranged from $2.25-4.28 \mathrm{~N}$ (Table 6). The increasing porang flour addition, produced the chicken sausage which lower hardness level. The declining of hardness is due to the porang powder is a hydrocolloid glucomannan that act as binding agents. It binds the components or raw materials of chicken sausage to be strong and compact. Porang flour has greater water binding ability which can reach $1900 \%$ compared to tapioca flour which only $30 \%$. When steaming process is done, product elasticity become higher. Anggraeni (2014) stated that starch and hydrocolloid collaboration is more susceptible to 
gelatinization characterized by faster viscosity increase compared to $100 \%$ starch. In general, the starch interacted with hydrocolloids has the same gelatinization profile pattern with starch without hydrocolloids.

\begin{tabular}{llll}
\multicolumn{4}{c}{ Table 6. The chicken sausage characteristics based on porang and tapioca flour proportion } \\
\hline Porang : Tapioca (g) & Water content (\%) & Carbohydrate (\%) & Texture (N) \\
\hline S1 $(0: 20)$ & $70,06 \mathrm{~b}$ & $11,51 \mathrm{~d}$ & $4,28 \mathrm{~d}$ \\
S2 $(1: 19)$ & $70,66 \mathrm{c}$ & $10,30 \mathrm{~d}$ & $3,40 \mathrm{c}$ \\
S3 $(2: 18)$ & $71,96 \mathrm{~d}$ & $8,43 \mathrm{c}$ & $3,10 \mathrm{bc}$ \\
S4 $(3: 17)$ & $73,03 \mathrm{~d}$ & $6,78 \mathrm{~b}$ & $2,97 \mathrm{bc}$ \\
S5 $(4: 16)$ & $73,65 \mathrm{de}$ & $5,68 \mathrm{ab}$ & $2,87 \mathrm{~b}$ \\
S6 $(5: 15)$ & $74,18 \mathrm{e}$ & $4,44 \mathrm{a}$ & $2,67 \mathrm{~b}$ \\
S7 $(6: 14)$ & $74,37 \mathrm{e}$ & $3,71 \mathrm{a}$ & $2,25 \mathrm{a}$ \\
Control & $63,37 \mathrm{a}$ & $21,39 \mathrm{e}$ & $2,12 \mathrm{a}$ \\
\hline
\end{tabular}

Based on Table 7 showed that the average of chicken sausage lightness ranged from 51.77 to $66.40 \%$. The increasing porang flour decreased the lightness level of chichken sausage. This brightness level is influenced by the filler basics color, alike porang flour has a brownish yellow, while tapioca flour has white color. While the reddish scale of chicken sausages ranged from 2.27 to 4.37 . The enhancement of porang flour usages increased the redness of the chicken sausage. This is because of several porang tubers have reddish yellow. So the porang powder has a higher natural red color element when compared with tapioca flour. Then yellowish intensity scale of chicken sausage ranged from 7.9 to 11.3. It was consistent with lightness, when porang flour increase made darker chicken sausage and decreasing yellowish level.

Table 7. The chicken sausage colours based on porang and tapioca flour proportion

\begin{tabular}{|c|c|c|c|}
\hline \multirow{2}{*}{ Porang: Tapioca Proportion (g) } & \multicolumn{3}{|c|}{ Colour Intensity } \\
\hline & $\mathrm{L}$ & $a^{+}$ & $b^{+}$ \\
\hline $\mathrm{S} 1(0: 20)$ & 66,40 & 2,27 & 11,30 \\
\hline $\mathrm{S} 2(1: 19)$ & 61,67 & 3,27 & 10,47 \\
\hline $\mathrm{S} 3(2: 18)$ & 60,57 & 3,53 & 9,93 \\
\hline $\mathrm{S} 4(3: 17)$ & 56,90 & 4,20 & 9,70 \\
\hline S5 $(4: 16)$ & 55,20 & 3,63 & 8,07 \\
\hline $\mathrm{S} 6(5: 15)$ & 53,00 & 4,00 & 7,90 \\
\hline S7 $(6: 14)$ & 51,77 & 4,37 & 9,07 \\
\hline Control & 63,67 & 5,10 & 14,77 \\
\hline
\end{tabular}

The organoleptic test results was shown Table 8. Commonly, the results showed that increasing porang flour decreased the organoleptics score, included taste, aroma, appearance, and favorite product. It because of porang gel could absorb water opimally, so it will realese the spice which added. The score ranged $2,93-3,50$ which described the taste was neutral to delicious. While, aroma score 
showed tasty $(3,00-3,47)$, the appearance indicated unattractive upto interesting $(2,47-3,87)$, and the most favorite product was porang flour 2 gram with 18 gram of tapioca $(3,70)$. According to Soekarto (2000), the most character which able to attract consumen is appearance (colour).

Table 8. The chicken sausage organoleptics based on porang and tapioca flour proportion

\begin{tabular}{lllllllll} 
Porang : Tapioca Proportion $(\mathrm{g})$ & \multicolumn{10}{c}{ Organoleptic } \\
\cline { 2 - 10 } & Taste & & Aroma & & Appearance & Favorite \\
\hline S1 $(0: 20)$ & 3,37 & ab & 3,47 & b & 3,87 & $\mathrm{c}$ & 3,50 & $\mathrm{bc}$ \\
S2 $(1: 19)$ & 3,50 & ab & 3,43 & ab & 3,63 & $\mathrm{c}$ & 3,67 & $\mathrm{bc}$ \\
S3 $(2: 18)$ & 3,30 & $\mathrm{ab}$ & 3,27 & $\mathrm{ab}$ & 3,07 & $\mathrm{~b}$ & 3,70 & $\mathrm{bc}$ \\
S4 $(3: 17)$ & 3,23 & $\mathrm{a}$ & 3,23 & $\mathrm{ab}$ & 2,80 & $\mathrm{ab}$ & 3,37 & $\mathrm{~b}$ \\
S5 $(4: 16)$ & 3,20 & $\mathrm{a}$ & 3,20 & $\mathrm{ab}$ & 2,67 & $\mathrm{a}$ & 2,90 & $\mathrm{a}$ \\
S6 $(5: 15)$ & 3,00 & $\mathrm{a}$ & 3,13 & $\mathrm{a}$ & 2,60 & $\mathrm{a}$ & 2,60 & $\mathrm{a}$ \\
S7 $(6: 14)$ & 2,93 & $\mathrm{a}$ & 3,00 & $\mathrm{a}$ & 2,47 & $\mathrm{a}$ & 2,53 & $\mathrm{a}$ \\
Control & 3,73 & $\mathrm{~b}$ & 3,40 & $\mathrm{ab}$ & 3,90 & $\mathrm{c}$ & 3,83 & $\mathrm{c}$ \\
\hline
\end{tabular}

\section{Conclusion}

Purification of porang flour using ethanol $90 \%$ was the best with glucomannan $58,20 \%$, rendemen $78,11 \%$, and viscosity $3,33 \mathrm{dPas}$. while the lightness 54,57 and yellowis 7,77. Substitution of porang flour $1 \mathrm{~g}$ : tapioca flour $19 \mathrm{~g}$ produces chicken sausage with moisture content $70,66 \%$, ash content $2,19 \%$, protein content $13,52 \%$, fat content $3,34 \%$, carbohydrate $10,3 \%$, and a texture of $3.4 \mathrm{~N}$, good taste, pleasant aroma, attractive appearance and favored by panelists.

\section{References}

Agustina, F. 2011. Ubi kayu. http://eprints.undip.ac. Diakses 28 Februari 2015.

Anggraeni. 2014. Proporsi Tepung Porang dan Maizena terhadap Karakteristik Sosis Ayam - Jurnal Pangan dan Agroindustri Vol. 2 No 3 p.214-223, Universitas Brawijaya : Malang.

Arifin. 2011. Pengaruh Perbandingan Tepung Tapioka dan Tepung Maizena Terhadap Mutu Tempura Ikan Kuniran (Upeneus sulphureus). Teknologi Hasil Perikanan. Universitas Brawijaya. Malang

Badan Standarisasi Nasional (BSN). 1995. SNI Sosis Daging (SNI 01-3820-1995). Badan Standarisasi Nasional. Jakarta.

Eka, A.S., Olim, dan M. Endang. 2014. Pemurnian Tepung Glukomanan Dari Umbi Porang (Amorphophallus muelleri Blume) Menggunakan Proses Ekstraksi/Leaching Dengan Larutan Etanol. Surakarta. Universitas Sebelas Maret.

Fellow, A.P. 2000. Food Procession Technology, Principles and Practise.2nd ed. Woodread.Pub.Lim. Cambridge. England. Terjemahan Ristanto.W dan Agus Purnomo.

Shiroh. 2000. Clarified Konjac Glucomannan. Error! Hyperlink reference not valid..

Soekarto. 2000. Dasar-dasar Pengawasan dan Standarisasi Mutu Pangan. Institut Pertanian Bogor. Bogor.

Tadahiko, T., 2003. Process for Producing Glucomannan Gel Particles. United States Patent 6558652. tanggal akses 19 Desember 2009.

Yusuf H., 2011. Jurnal Teknologi Pertanian Vol 12 No.3. Hal. 143-152. Universitas Brawijaya. Malang. 